\title{
Analiza influenței disturbanțelor asupra diversității speciilor forestiere din Ocolul silvic Râșca folosind modelul LandClim
}

\author{
C. Goșofreț, C. Palaghianu, L. Bouriaud
}

Coșofreț C., Palaghianu C., Bouriaud L. 2021. Analysis of the disturbances influence on tree species diversity from Râșca forest district using LandClim model. Bucov. For. 21(1): 19-32

Abstract. The diversity of forest tree species varies widely between different areas or regions. Tree species diversity is a direct way of assessing biodiversity and the Shannon entropy index is the most commonly used. The LandClim model is suitable for capturing the dynamics of forest vegetation at large temporal and spatial scales as well as the effects of disturbances on diversity that differ depending on climate, environment or location of disturbed ecosystems. The paper aims to identify how the tree species diversity is affected by disturbances in a climate scenario that projects low-impact climate change. It also wants to clarify how tree species diversity reacts at different altitudes and aspect classes.

The simulations show that as the intensity and size of the disturbances increase, from the scenario without disturbances to mixed disturbances, the values of tree species diversity increase. At the same time, the rise in altitude leads to a differentiation of tree species diversity between disturbance scenarios and at extreme elevation, the tree species diversity evolution is more strongly influenced by aspect while. In contrast, intermediate altitudes offer a relatively constant tree species diversity in mixed and anthropogenic disturbances.

The simulations of the specific composition dynamic show the disturbances effects on tree species diversity which need understood and included in the forest management system. The positive effects, increasing tree species diversity, should be exploited by preserving the pioneer species initially installed avoiding excessive homogenization of forest stands, sometimes imposed by too rigid technical norms. Using the ecosystem response and incorporating the positive effects of natural disturbances in forest management can be an appropriate way to create stands more adapted to climate change.

Keywords: disturbances, species diversity, LandClim model.

Authors. Cosmin Coşofreț (cosmin.cosofret@usm.ro), Ciprian Palaghianu, Laura Bouriaud, "Ștefan cel Mare" University of Suceava, Faculty of Forestry, 13 Universității, 720229 Suceava, Romania.

Manuscript: received May 13, 2021; revised May 27, 2021; accepted May 28, 2021; online first May 30, 2021. 


\section{Introducere}

Diversitatea speciilor forestiere variază în limite largi între diferite zone sau regiuni, în funcție de factorii care modelează particularități specifice unor comunități vegetale. Modul în care aceste comunități au evoluat sau continuă să se transforme intrigă specialiștii, numeroase teorii fiind propuse de-a lungul timpului (Gaston 2000, Mittelbach și Schemske 2015). Multe dintre ipotezele propuse implică abordări care utilizează modelarea matematică a sistemelor, pentru a simplifica analiza și înțelegerea complexității interacțiunilor ecologice ce se desfãșoară la diferite scări spaţio-temporale (Pontarp et al. 2019, Read et al. 2020). Chiar dacă anumite procese individuale care influențează structura și biodiversitatea ecosistemelor sunt identificate și înțelese, interacțiunile spațio-temporale desfășurate la o scară largă depăşesc capacitatea analitică a unor modele matematice simplificate (Rangel et al. 2018).

Înțelegerea particularităților dinamicii biodiversității și a relației acesteia cu gradienții de mediu este o problemă cheie în ecologia forestieră și conservarea biodiversităţii (Brunialti şi Frati 2021), cu implicaţii directe în managementul silvic. Diversitatea specifică reprezintă o modalitate directă de evaluare a biodiversității, fiind o caracteristică esențială a structurii pădurilor (Pommerening 2002) ce poate influența funcțiile acestora (Nadrowski et al. 2010). Din multitudinea de indici de evaluare a diversităţii specifice, indicele de entropie Shannon este cel mai frecvent utilizat, luând în considerare numărul de specii din fiecare celulă a matricei și abundența lor relativă (Neumann și Starlinger 2001).

Modelele la nivel de peisaj sunt mai potrivite pentru a surprinde dinamica vegetaţiei forestiere la scări temporale și spaţiale mari, cât și efectele unor disturbanțe (tratamente bazate pe tăieri repetate și regenerare sub masiv, incendii sau doborâturi de vânt) (He 2008). Datorită extinderii rezoluției spațiale, pădurile sunt împărțite în celule, reprezentate la nivel de peisaj sub forma unei matrici de astfel de unități elementare. Fiecare celulă a matricei este caracte20 rizată de anumite atribute specifice: compoziție, clasă de vârstă, biomasă, număr de arbori, diametru de bază sau înălțime (Taylor et al. 2009). Totodată, pentru fiecare celulă a matricei se regăsesc și informații legate de factorii ce pot influenţa comunitatea: altitudine, pantă, expoziție sau tip de sol. În acest fel, modelele de dinamică a peisajului pot simula pe scară largă și perioade îndelungate de timp efectele disturbanțelor asupra dinamicii compoziției și structurii arboretelor (Henne et al. 2013, Scheller și Mladenoff 2007).

Modelul LandClim, utilizat și în cazul de față, este unul dintre modelele frecvent utilizate de către cercetători (Bouriaud et al. 2014, Schuler et al. 2019, Thrippleton et al. 2018), fiind dezvoltat pentru a identifica impactul pe termen lung al topografiei terenului, schimbărilor climatice, gestionării pădurilor și disturbanțelor asupra serviciilor ecosistemelor forestiere (Schumacher et al. 2006, Schumacher şi Bugmann 2006).

Interacțiunile dintre dinamica peisajului și diversitatea specifică sunt determinate de o serie de disturbanțe, evenimente discrete în timp şi spațiu care pot să inducă efecte la nivelul ecosistemelor forestiere sub forma unor perturbări. Deși diferențele semantice dintre termenii disturbanță și perturbare sunt uneori neclare (Battisti et. al 2016, Pickett și White 2013), în cazul acestui articol se va folosi terminologia propusă de Rykiel (1985), care identifică relația de cauzalitate dintre disturbanțe și perturbări. În acest sens, identificăm disturbanţele drept evenimentele ce declanșează transformări structurale sau funcționale ale unui sistem, resimțite ca efect sub forma perturbărilor.

Influența evenimentelor disturbante asupra dinamicii peisajului forestier este tot mai intensă, modificările induse ecosistemelor având atât cauze naturale, cât și antropice (Seidl et al. 2011).

Cercetările de până acum au arătat că disturbanțele naturale pot duce la o creștere a diversității speciilor (Sousa 1984, White 1979), idee cu implicații ecologice deosebite, deoarece creșterea diversității conduce la sporirea stabilității și capacității de funcționare a eco- 
sistemelor (Brose și Hillebrand 2016, Isbell et al. 2011). Totuși, problema disturbanțelor ca factor de amplificare a diversității speciilor reprezintă un subiect încă dezbătut în literatura de specialitate, datorită faptului că relația dintre diversitate și disturbanțe/perturbări a fost interpretată în moduri foarte variate (Mackey și Currie 2001, Robin Svensson et al. 2012, Yeboah și Chen 2016).

Există studii care au arătat că disturbanțele de intensitate medie pot conduce la o creștere a diversității (Martinsen et al.1990) dar, sunt şi studii care indică faptul că şi la alte niveluri ale intensității disturbanțelor poate avea loc o majorare a diversității (Abensperg-Traun et al. 1996). Pe de altă parte, sunt cercetări care au arătat că, în anumite situații, diversitatea pare să nu fie influențată de disturbanțe (Jullien și Thiollay 1996, Schuler et al. 2019).

Topografia terenului (White și Jentsch 2001), compoziția și structura diferită a arboretelor (Silva Pedro et al. 2016) sau intensităţi și frecvente variate ale unor disturbanțe (Miller et al. 2011), pot duce la rezultate contradictorii în ceea ce privește dinamica diversității specifice (Schuler et al. 2019).

Disturbanţele par să acționeze contextual, efectele asupra diversităţii specifice fiind diferite în funcție de anumite particularități climatice sau de amplasare a ecosistemelor afectate.

Scopul lucrării este de a identifica modul în care este afectată diversitatea speciilor forestiere de disturbanțe într-un scenariu climatic care proiectează schimbări cu un impact redus și care este evoluția diversității speciilor la diferite clase altitudinale și de expoziție în cadrul unui ocol silvic situat în zona de munte (nordul Carpaţilor Orientali).

\section{Material și metodă}

\section{Localizare}

Ocolul silvic Râşca este situat în partea de nord-est a României (Fig. 1), la altitudini cuprinse între 400 şi $1200 \mathrm{~m}$. În cadrul acestui ocol sunt întâlnite cu precădere arborete amestecate de brad și fag, cu un raport echilibrat între cele cu structură echienă, respectiv plurienă.

Pentru a determina panta, altitudinea și expoziția pentru zona studiată a fost construit modelul digital al terenului utilizând curbele de nivel și punctele cotate vectorizate pe planuri de bază 1:5000 (Anonymous 2010). S-a folosit modulul Topo to Raster al programului ArcGIS 9.3 pentru a genera modelul digital al terenului cu o dimensiune a celulei de $25 \mathrm{~m}$, fiind create clase altitudinale de 100 de metri.

Modelul a fost folosit în continuare pentru a determina expoziția, cu ajutorul extensiei Spatial Analyst. Valorile expoziţiei sunt grupate în următoarele categorii: N (0-22,5 și 337,5-360), NE (22,5-67,5), E (67,5-112,5), SE (112,5-157,5), S (157,5-202,5), SV (202,5247,5), V (247,5-292,5), NV (292,5-337,5). Pentru a spori relevanța prelucrărilor și rezultatelor, expoziția a fost clasificată în patru clase: parțial umbrită (E, SE), însorită (S, SV), parțial însorită (V, NV), umbrită (N, NE) (Fig. 2).

\section{Modelul LandClim}

Modelele, care simulează dinamica pădurii la nivel de peisaj, sunt sensibile la parametrii (sau datele) de intrare, iar descrierea incorectă a caracteristicilor arboretului poate avea consecințe negative asupra rezultatelor obținute (Bouriaud et al. 2014, Temperli et al. 2013). Informațiile despre compoziția arboretelor, volum, vârstă și clasă de producție pentru fiecare unitate amenajistică au fost extrase din amenajamentul ocolului silvic Râșca.

Pentru a putea obține rezultatele dorite, în cadrul modelului LandClim au fost create fișiere de intrare, cu informațiile ce definesc contextul modelării:

(i) altitudinea, expoziția și panta au fost extrase din modelul terenului în raport cu centrul fiecărei celule și au fost create fișiere raster cu dimensiunea celulei de $25 \times 25 \mathrm{~m}$;

(ii) informații despre tipul de sol și arboret au fost extrase din tabelul de atribute; 


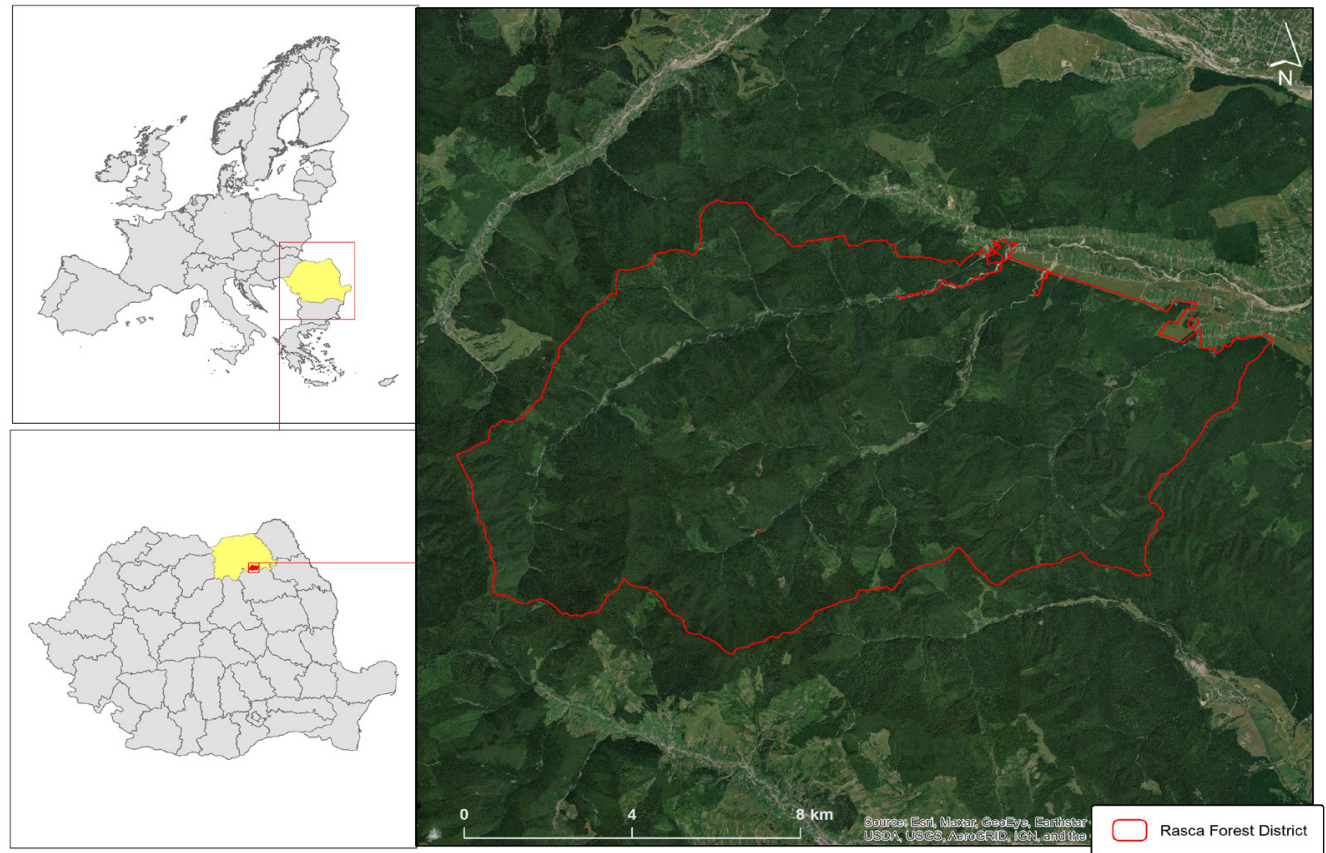

Figura 1 Localizare Ocol silvic Râșca

Location of Râşca forest district

(iii) date climatice: temperaturi şi precipitații lunare;

(iv) lista de specii existente în OS Râșca și exigențele acestora;

(v) cantitatea de apă disponibilă în sol (AWC) a fost simulată pentru fiecare celulă în funcție de altitudine, expoziție și pantă în raport cu cele două tipuri principale de sol: eutricambosol (49\%) şi districambosol (41\%).

(vi) masca (fişierul raster) care face diferen-

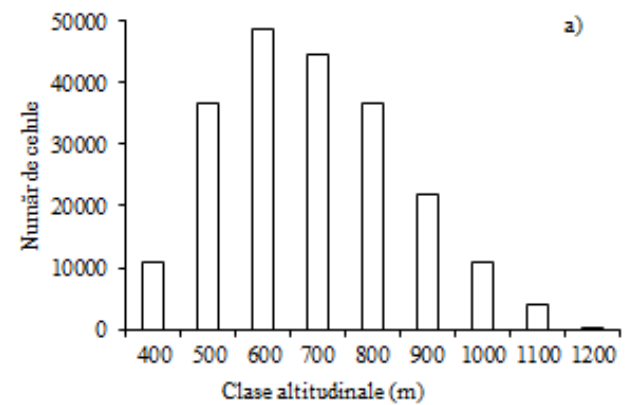

țele dintre: păduri de stat, administrate de OS Râșca, pășuni sau terenuri neproductive;

(vii) fișierul raster cu tipul de gestiune a pădurii a fost atribuit fiecărei celule;

(viii) fișierul raster cu numărul fiecărei unități amenajistice ce este atribuit fiecărei celule.

Ţinând cont de disponibilitatea datelor şi de complexitatea modelului LandClim, considerăm că modelul este adecvat analizei evoluției stării pădurilor din OS Râşca, în diferite sce-

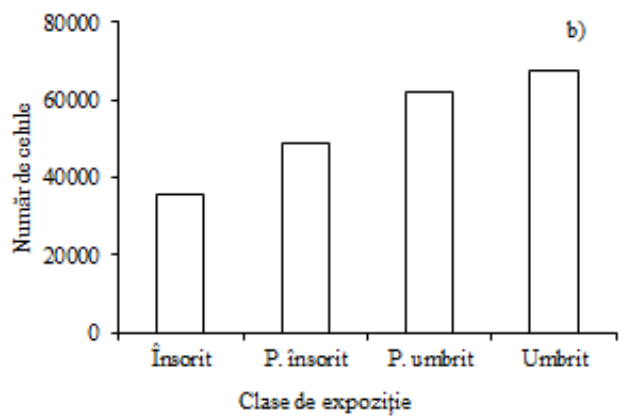

Figura 2 Distribuția claselor altitudinale (a) și de expoziţie (b) Distribution of elevation (a) and aspect (b) classes 
Tahel1 Evoluția temperaturii și precipitațiilor în scenariul climatic CCSM3

Temperature and rainfall evolution in the CCSM3 climate scenario

\begin{tabular}{lcccccccccc}
\hline media pe decadă & 1 & 2 & 3 & 4 & 5 & 6 & 7 & 8 & 9 & 10 \\
\hline $\begin{array}{l}\text { temperatura medie } \\
\text { anuală }\left({ }^{\circ} \mathrm{C}\right)\end{array}$ & 6,6 & 7,1 & 7,2 & 7,7 & 7,9 & 8,4 & 8,4 & 8,3 & 8,5 & 8,4 \\
$\begin{array}{l}\text { suma precipitațiilor } \\
\text { anuale }(\mathrm{mm})\end{array}$ & 701,1 & 655,7 & 646,2 & 634,7 & 608,3 & 586,9 & 624,1 & 594,3 & 616,8 & 586,4 \\
\hline
\end{tabular}

narii climatice și tipuri de perturbări. Modelul a fost aplicat fără modificări ale parametrilor interni care definesc procesele de bază și trăsăturile arborilor cum ar fi toleranța la umbră, limite de temperatură, creșterea maximă anuală a biomasei și parametrii modelelor de creștere (Schumacher și Bugmann 2006).

Modelul LandClim produce o varietate de rezultate pentru fiecare celulă, precum lista speciilor, desimea arborilor și biomasa acestora, diametrul de bază, înălțimea și vârsta. Aceste variabile pot fi utilizate pentru a calcula biomasa existentă, biomasa recoltată si serviciile ecosistemice de aprovizionare și de reglare (ex: diversitatea speciilor de arbori) (Snell et al. 2018).

Pentru a evalua impactul schimbărilor climatice și a disturbanțelor asupra pădurilor, în simulările realizate a fost utilizată proiecția climatică CCSM3, obținută din combinația modelelor GCM/RCM din scenariul de emisii A1B (IPCC 2007). Scenariul climatic RCA30/ CCSM3 conduce spre cele mai reduse schimbări climatice (Kjellström et al. 2011), cantitățile de precipitații preconizate scăzând cu 115 $\mathrm{mm}$, iar temperatura medie crescând cu $1,8^{\circ} \mathrm{C}$ la finalul simulării (Tab. 1). Aceste diferențe creează incertitudini în ceea ce privește modul în care viitoarele evenimente climatice extreme vor influența gestiunea pădurilor în viitor (Zimmermann et al. 2013).

\section{Diversitatea speciilor}

Diversitatea speciilor forestiere este frecvent evaluată folosind indicatori sintetici (Palaghianu 2014). În acest caz, pentru a putea compara ușor valorile obținute s-a folosit indi- cele Shannon, valoarea acestuia fiind calculată pentru fiecare celulă:

$$
H=-\sum_{i=1}^{k} \frac{n_{i}}{N} \ln \frac{n_{i}}{N}
$$

unde: $k$ este numărul de specii dintr-o celulă; $n_{i}$ reprezintă numărul de arbori din specia $i$; și $N$ este numărul total de arbori dintr-o celulă. Indicele Shannon variază ca limite între 0 și $\ln (k)$. Valorile mici ale indicelui Shannon se ating atunci când se înregistrează o omogenitate specifică mare, majoritatea indivizilor aparținând unei singure specii. Viceversa, valori mari, ce indică heterogenitate, se obțin atunci când repartizarea numărului de arbori pe specii diferite este relativ echilibrată. În studiul de față s-a calculat diversitatea speciilor după numărul de arbori care depășesc diametrul de $5 \mathrm{~cm}$.

\section{Tipuri de disturbanțe}

Disturbanțele, evenimente care pot genera transformări profunde ale ecosistemelor, au cauze diferite, cel mai adesea fiind clasificate, din acest punct de vedere, în disturbanțe antropice și naturale.

Disturbanțele antropice, în cazul ecosistemelor forestiere, sunt reprezentate de managementul silvic, sau, mai explicit, de activitățile de exploatare a pădurilor. În cadrul modelului LandClim, în modulul de exploatare sunt definite diferite intensităţi ale răriturilor şi a tratamentelor cu tăieri repetate și regenerare (prag limită al biomasei) sub masiv în funcție de clasa de producție a arboretelor. Exploatarea se poate declanşa doar atunci când este atins pragul limită al biomasei. Pe lângă partea de 
exploatare, în modul există și partea de regenerare unde poate fi precizată desimea și speciile pe care dorim sa le introducem (Material Suplimentar, Tab. 1).

Disturbanțele naturale sunt cele provocate de vânt sau foc. Pentru a include în cadrul modelului și aceste tipuri de evenimente, parametrii din model au fost setaţi și adaptaţi la condițiile locale.

Modulul doborâturilor provocate de vânt necesită parametri specifici pentru fiecare studiu de caz: dimensiunea minimă, medie și maximă a doborâturii provocate de vânt (în metri pătrați), coeficientul de mărime și intervalul mediu de revenire a evenimentelor.

În studiul de față, aceste dimensiuni au fost deduse din literatura de specialitate și adaptate la specificul local. Dimensiunea minimă a unei doborâturi a fost estimată la 0,5 ha (Marcean 2002), cea medie la 40 ha, iar cea maximă la 100 ha (Simionescu et al. 2012).

Caracteristicile doborâturilor au fost estimate pe baza istoricului acestora în județul Suceava (Marcean 2002, Popa 2004). În județul Suceava, în ultimii 70 de ani, doborâturile au avut loc o dată la fiecare 7-10 ani (Marcean 2002) iar cea mai puternică doborâtură care a fost înregistrată (1977) a afectat un volum de lemn de 8 milioane $\mathrm{m}^{3}$.

Pentru a estima coeficientul de mărime al unei doborâturi s-a recurs la o prelucrare a informaţiilor istorice. Volumul de lemn afectat de doborâtura din anul 1977 a fost împărțit la 300 $\mathrm{m}^{3} /$ ha (volumul mediu/ha în zona montană) rezultând, o suprafață de aproximativ 27000 ha. Prin urmare, proporția suprafeței afectate (coeficientul de mărime) este de 0,065 dintr-un total de 410000 ha de păduri din județul Suceava (Popa 2004), iar intervalul mediu de revenire al doborâturilor catastrofale, similare celor din anul 1977, a fost estimat la 165 de ani.

Modulul de incendii al LandClim a fost testat pentru a vedea dacă modelul simulează rezultate realiste (Schumacher 2004). Curba de răspândire a incendiilor este data de coeficientul de probabilitate care poate fi conservativ sau poate simula o frecvență mai mare 24 a incendiilor. În cazul de faţă s-a ales varianta conservativă, ținând cont de faptul că suprafața medie afectată de incendii în județul Suceava, în perioada 1990-2009, a fost de doar 2,5 ha (Burlui 2013).

Simularea disturbanțelor a inclus scenarii diferite: disturbanţe antropice, naturale, mixte şi simularea fără disturbanțe. Simularea disturbanțelor mixte a constat atât în activarea modulului exploatare, cât și a modulelor doborâturi și incendii. Varianta fără existența disturbanțelor, a fost inclusă pentru a identifica care dintre simulările considerate influențează cel mai mult evoluția diversităţii într-un scenariu climatic cu impact redus.

Intervalul pe care s-a derulat simularea a fost de 100 de ani, cuprins între 2010 și 2110.

Analizele tuturor rezultatelor furnizate de model au fost efectuate în programul statistic R, versiunea 3.6.2 (R Core Team 2019) cu ajutorul pachetelor și colecțiilor de funcții specifice analizelor statistice din mediul RStudio (Rmisc, sqldf și ggplot2).

\section{Rezultate}

Toate rezultatele obținute se bazează pe evaluarea diversității specifice prin intermediul valorilor indicelui Shannon.

Dacă se analizează diferențele modului de evoluție a diversităţii în condițiile scenariilor propuse (Fig. 3), fără a se separa rezultatele pe categorii de altitudine sau expoziţie, se observă o stratificare clară între ele. Se poate observa, pentru zona studiată, că valorile minime ale diversității se înregistrează în condițiile scenariului care nu prevede disturbanțe. În același timp, valorile maxime ale diversităţii se obțin în condițiile scenariului cu disturbanțe mixte, valorile intermediare, în ordine descrescătoare, fiind corespunzătoare scenariilor cu disturbanțe individuale antropice, respectiv scenariilor cu disturbanțe individuale naturale. Rezultatele corespunzătoare disturbanțelor mixte şi antropice se diferenţiază puternic de disturbanțele naturale, iar în a doua jumătate a 


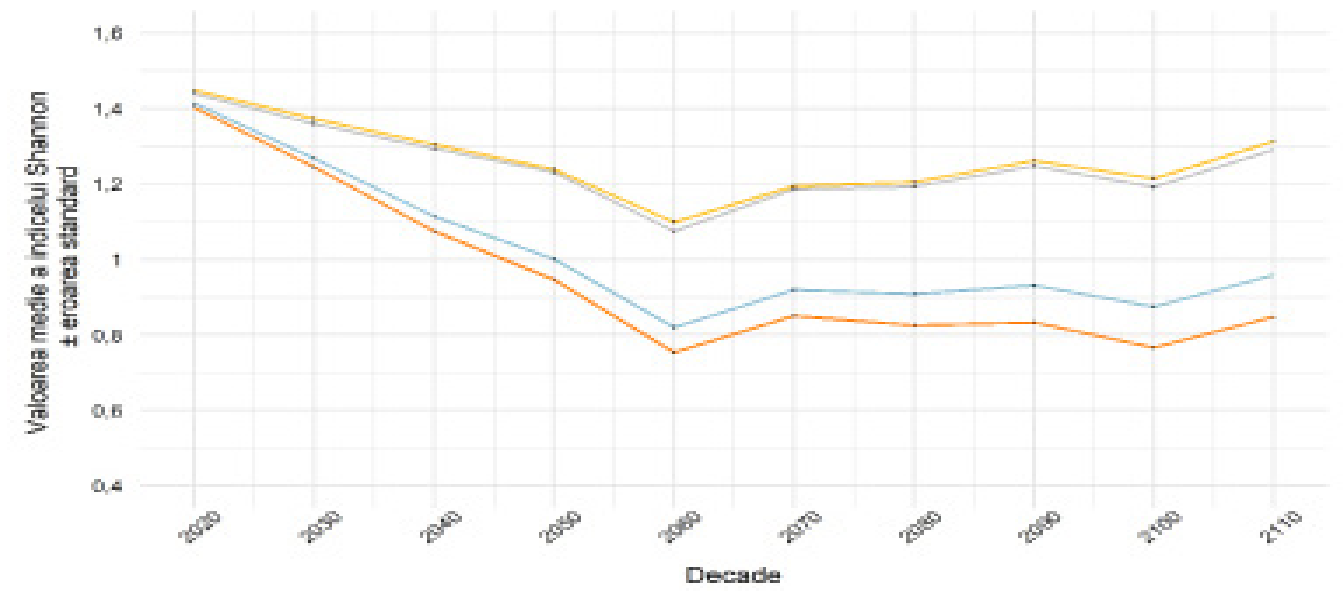

Figura 3 Evoluția diversității speciilor sub diferite scenării ale disturbanțelor

*linia galbenă - disturbanțe mixte, linia gri - disturbanțe antropice, linia albastră - disturbanțe naturale, linia portocalie - fără perturbări

Species diversity evolution under different disturbance scenarios

*yellow line - mixed disturbance, grey line - anthropic disturbance, blue line - natural disturance, orange line - no disturbance

intervalului simulării apare o dihotomie și mai evidentă nu doar la nivelul valorilor, dar și al tendinței de evoluție. Dacă, în cazul disturbanțelor mixte și antropice, tendința de evoluție a diversității este evident crescătoare, în cazul disturbanțelor naturale tendința este mai degrabă de plafonare.

Analizând ierarhizarea valorilor indicilor Shannon, în funcție de scenariile stabilite, se poate aprecia că, odată cu creșterea intensității şi dimensiunii disturbanțelor, de la scenariul fără disturbanțe spre cel cu disturbanțe mixte, se majorează valorile diversității speciilor.

A fost analizat și modul în care diversitatea speciilor evoluează în cadrul scenariilor stabilite pe diferite clase altitudinale şi de expoziție. Tendinţa observată anterior, de diferenţiere între scenarii, s-a remarcat și în cazul acestor analize pe clase, înregistrându-se valori ridicate ale diversităţii speciilor în cazul disturbanțelor mixte și antropice și scăzute în cazul disturbanțelor naturale sau lipsei disturbanțelor.

În cazul analizei pe categorii altitudinale, diferențele între clasele 500 m, 700 m, 900 m şi $1100 \mathrm{~m}$, sunt clar evidenţiate (Fig. 4). În cadrul clasei de 500 de m, evoluția diversității este similară pentru toate scenariile simulate, fiind înregistrată o scădere a acesteia în prime- le cinci decenii, pentru ca mai apoi, după creșterea din deceniul al șaselea, să se stabilizeze într-un plafon mediu. În cadrul clasei de 700 $\mathrm{m}$, scăderea din primele decade ale indicelui Shannon este mai uniformă, iar în ultimii 50 de ani ai simulării se observă o ușoară creștere a diversității, în cazul scenariilor ce includ disturbanţe mixte și antropice.

La altitudini mai mari (clasele de $900 \mathrm{~m}$ și $1100 \mathrm{~m}$ ), diferențierea dintre diversităţile corespunzătoare scenariilor disturbanțelor mixte şi antropice este mult mai evidentă prin comparație cu cele obținute pentru scenariile disturbanțelor naturale și lipsei disturbanțelor.

Clasa altitudinală de 900 m este cea pentru care se înregistrează maximul diversităţii specifice, corespunzătoare disturbanțelor mixte și antropice. Valori mai mari ale diversității în cadrul clasei de 900 de metri sunt observate și în cazul simulării fără disturbanțe sau cu disturbanțe naturale, comparativ cu valorile corespunzătoare clasei de 1100 de metri.

Remarcabil pentru categoria altitudinală maximă (1100 m) este faptul că, spre finalul perioadei de simulare, se obține cea mai clară diferențiere între valorile obținute pentru cele patru scenarii considerate.

Se poate aprecia, ținând cont că în cadrul 

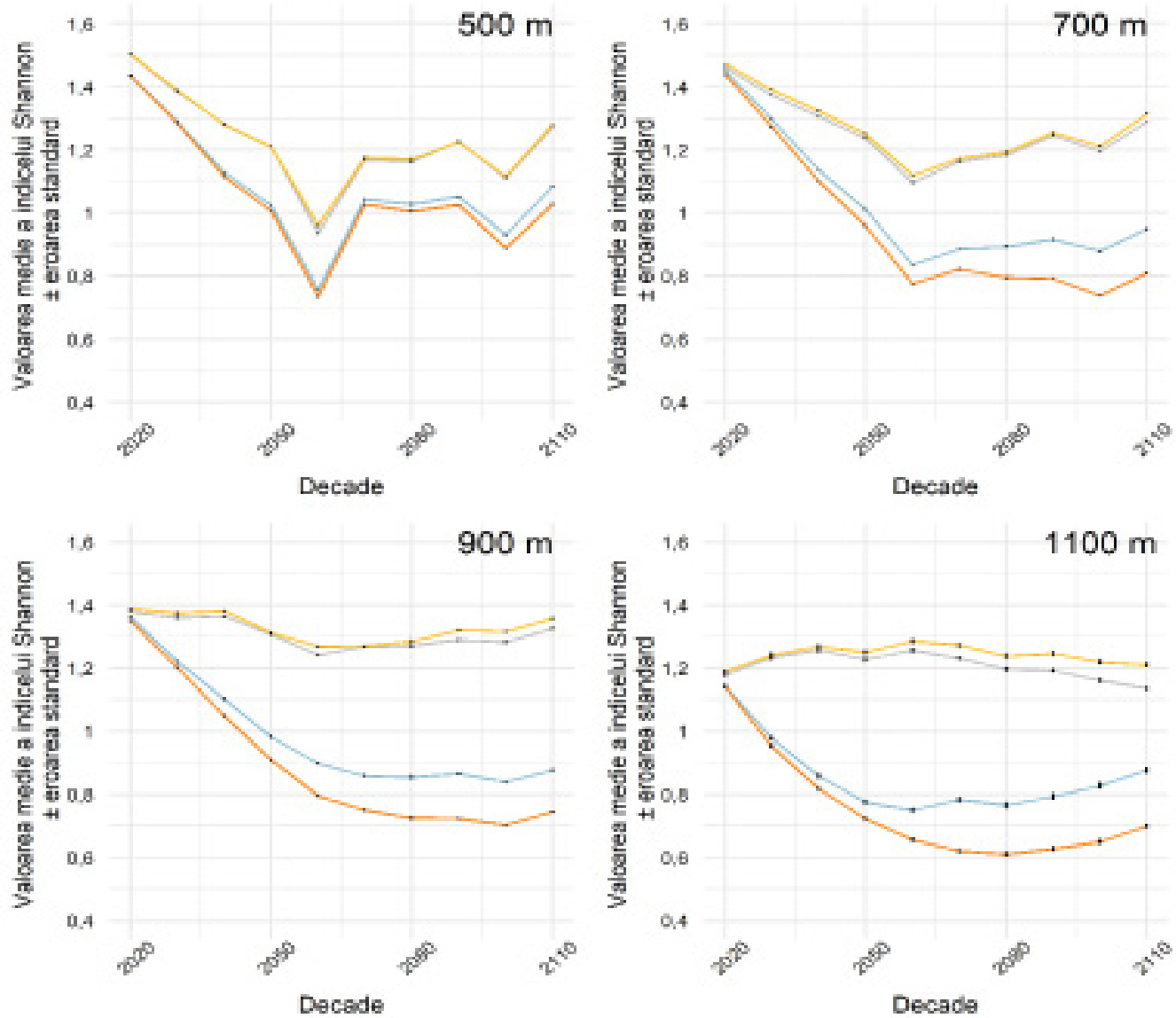

Figura 4 Evoluția diversității speciilor la diferite clase altitudinale

*linia galbenă- disturbanțe mixte, linia gri - disturbanțe antropice, linia albastră - disturbanțe naturale, linia portocalie - fără perturbări

Species diversity evolution at different classes of elevation

*yellow line - mixed disturbance, grey line - anthropic disturbance, blue line - natural disturbance, orange line - no disturbance

clasei de 500 m se observă cea mai strânsă diferențiere între valorile diversității, iar în cadrul clasei de 1100 m cea mai amplă, că, o dată cu creșterea altitudinii, are loc o diferențiere mai clară a diversităţii între scenarii, fapt ce arată dependența diversităţii la altitudine.

În cazul analizei diferențelor înregistrate pe categorii de expoziție, există deosebiri clare, corespunzătoare claselor cu expoziție însorită, parțial însorită, umbrită și parțial umbrită (Fig. 5).

În cadrul clasei de $500 \mathrm{~m}$, evoluţia diversității este diferită pentru toate clasele de expoziție. Pe expozițiile însorită, parțial umbrită și umbrită, evoluția diversității în simularea cu disturbanțe mixte nu se diferențiază de cea cu disturbanțe antropice, iar simularea disturbanțelor naturale nu se diferențiază de simularea fără disturbanțe. În cazul expoziției parțial umbrite, în ultimii 50 de ani ai simulării nu mai există diferențe între tipul de disturbanțe, diversitatea păstrându-se la valori ridicate. Distinct de celelalte expoziții, pe cea parțial însorită se observă o diferențiere evidentă între grupul scenariilor cu disturbanțe antropice și mixte față de celelalte scenarii.

În cadrul clasei de $700 \mathrm{~m}$ pentru clasele de 

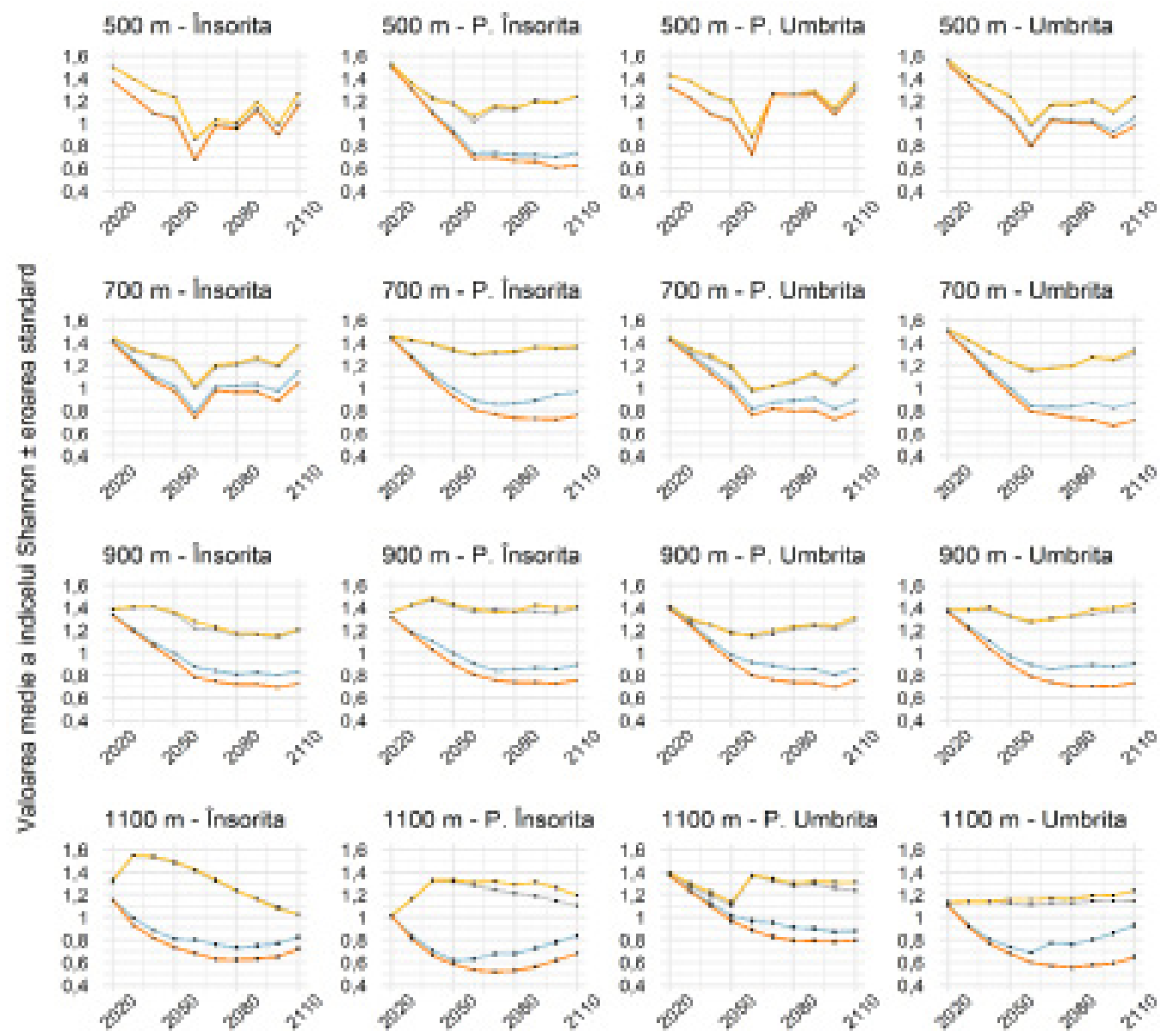

Decade

Figura 5 Evoluția diversității speciilor la diferite clase altitudinale și de expoziție

*linia galbenă- disturbanțe mixte, linia gri - disturbanțe antropice, linia albastră - disturbanțe naturale, linia portocalie - fără perturbări

Species diversity evolution at different classes of elevation and aspect

*yellow line - mixed disturbance, grey line - anthropic disturbance, blue line - natural disturbance, orange line - no disturbance

expoziție însorită și parțial umbrită este înregistrată o scădere a diversității în primele cinci decenii pentru toate scenariile simulate, pentru ca după al şaselea deceniu creșterea să fie mai accentuată în cazul expoziției însorite. În schimb, pe expozițiile parțial însorite și umbrite sunt înregistrate cele mai mari diferențe între grupul scenariilor cu disturbanț mixte și antropice, unde este înregistrat maximul diversității pe întreaga perioadă, și restul scenariilor.

Clasa altitudinală de $900 \mathrm{~m}$ este cea pentru care se înregistrează maximul diversității specifice, corespunzătoare disturbanțelor mixte și antropice pentru toate clasele de expoziție. În cazul scenariilor fără disturbanțe sau cu disturbanțe naturale, diversitatea specifică scade în primele cinci decade, ca apoi să se stabilizeze până la sfârșitul perioadei simulării. În cadrul clasei de 900 m se observă pentru toate clasele de expoziție cea mai clară diferențiere între grupul scenariilor cu disturbanțe antropice și mixte și cel al disturbanțelor naturale sau fără disturbanțe. 
Remarcabil, pentru categoria altitudinală maximă $(1100 \mathrm{~m})$, este faptul că, pentru toate clasele de expoziție, dinamica diversității diferă în toate scenariile disturbanțelor simulate. Evoluția diversității în scenariile de disturbanțe mixte şi antropice pe expoziția însorită este total diferită de cea pe expoziția umbrită, unde se observa evoluția cea mai constantă. Expoziția parțial umbrită oferă valori ridicate ale diversităţii în scenariile cu disturbanțe naturale sau fără disturbanțe, comparativ cu expoziția parţial însorită. În ceea ce privește disturbanțele mixte și antropice, acestea duc la o diferențiere în evoluție a diversității specifice în primele cinci decade, ca mai apoi, în a doua jumătate a simulării, să aibă valori ridicate şi constante.

Se poate aprecia, ținând cont de analiza pe clase de altitudine și de expoziție, că la altitudinile extreme, evoluția diversității este mai puternic influențată de expoziție. În schimb, altitudinile intermediare oferă o diversitate specifică relativ constantă în cazul disturbanțelor mixte și antropice și o diferențiere mai clară a diversității între scenariile considerate.

\section{Discuții}

Disturbanţele, prin efectele uneori disruptive asupra peisajului, afectează nu doar funcționalitatea, dar şi structura ecosistemelor forestiere, modificând diversitatea specifică a arboretelor (Seidl et al. 2011). Modul în care perturbările sunt resimțite de ecosistemele forestiere la nivel specific depinde foarte mult de anumite particularități climatice sau de amplasare (Ammer 2019, Seidl et al. 2014, 2017).

Rezultatele din lucrarea de față au fost obținute în urma analizei modului în care disturbanțele produse într-un scenariu climatic cu un impact redus influențează evoluția diversității speciilor la diferite clase altitudinale și de expoziție în arborete din zona montană.

Valorile indicelui Shannon, prin intermediul căruia s-a apreciat diversitatea specifică, au avut în acest caz limite largi, cuprinse între 0,8 28 și 1,4 , valorile acestui indice variind, în alte studii, în funcție de zona geografică, altitudine sau tipul de pădure, fiind întâlnite valori mai mici, de 0,65 în cazul arboretelor de fag din zona mediteraneeană (Redowan 2015), dar și valori mai mari, de 1,90-2,03 în arborete din nord-vestul Chinei (Jiang et al. 2007).

Este acceptat faptul că disturbanțele reprezintă motorul dinamicii peisajului, multe studii efectuate la nivelul peisajului forestier evidențiind o relație direct proporțională între perturbări și diversitatea specifică (Silva Pedro et al. 2016). Ecosistemele au reacții diferite și în timp, odată confruntate cu un regim al disturbanțelor, înregistrând o dinamică activă a diversității (Miller et al. 2011, Yeboah și Chen 2016), sesizată şi în cazul acestei simulări derulate pe o perioadă de 100 de ani.

Datorită faptului că tipul disturbanțelor modifică relația dintre perturbări și diversitate (Shea et al. 2004), în modelarea de față au fost incluse atât disturbanțele naturale specifice ecosistemelor forestiere (doborâturi de vânt și incendii cu parametri specifici adaptați la condițiile locale), cât și disturbanțele antropice, constituite de managementul silvic. Acestea din urmă au o selectivitate diferită la nivelul speciilor, fiind mai predispuse la a influența unidirecțional compoziția și diversitatea specifică (Feng et al. 2014).

În cazul de față, frecvența și intensitatea acestui tip de disturbanțe au fost adaptate condițiilor locale, constatându-se o influență mult mai mare a disturbanțelor antropice asupra diversității speciilor, comparativ cu cea exercitată de schimbările climatice pentru perioada de timp simulată. Acest lucru este înregistrat în condițiile în care sunt incluse în simulare și disturbanțele naturale, aspect remarcat și în cadrul altor studii (Mina et al. 2017).

Pe de altă parte, disturbanțele naturale conduc la creșterea diversităţii comparativ cu scenariile care nu au inclus disturbanțe în modelare. Scenariile care includ aceste disturbanțe cu relevanță spațială, precum vântul și focul, arată că efectul acestora generează un mozaic eterogen de arborete (Schuler et al. 2019), pe 
când lipsa disturbanțelor tinde să creeze arborete cu o diversitate scăzută a speciilor. Prin urmare, rezultatele studiului de față sunt în concordanță cu alte studii care arată că prezența disturbanțelor crește diversitatea specifică, creând peisaje mai eterogene.

Totuși, majoritatea studiilor au arătat că frecvența și intensitatea disturbanțelor influențează cel mai mult diversitatea (Miller et al. 2011, Shea et al. 2004, Yeboah și Chen 2016). Odată $\mathrm{cu}$ creșterea magnitudinii și frecvenței disturbanțelor se observă o majorare a valorilor diversității specifice (Silva Pedro et al. 2016). Rezultatele obținute în cadrul acestui studiu sunt similare cu cele înregistrate de alte studii, tendința de evoluție a diversităţii fiind crescătoare în cazul disturbanțelor mixte și antropice. Magnitudinea perturbărilor fiind agregativă, efectul de potențare a diversității în cazul scenariului disturbanţelor mixte (care include toate tipurile de disturbanțe) a fost resimțit atât în cazul simulării generale (Fig. 3), cât și al situațiilor analizate în funcție de altitudine sau expoziție (Fig. 3 și 4).

Referitor la modul în care altitudinea influențează diversitatea, studiile au arătat că arboretele de la altitudini joase sunt mai expuse disturbanțelor antropice şi naturale care afectează arborii de dimensiuni mari, fapt care permite speciilor mai puțin competitive să apară în compoziția arboretelor și să contribuie la creșterea diversității (Schuler et al. 2019).

În cazul de față, tendința de diferențiere între scenarii, observată pe simularea generală, s-a păstrat și în cazul analizei pe clase altitudinale, fiind înregistrate pentru toate clasele valori mai ridicate ale diversității speciilor în cazul disturbanțelor mixte și antropice comparativ cu cele obținute pentru disturbanțele naturale sau în cazul lipsei perturbărilor.

Dacă la altitudini reduse (clasa de 500 m) se observă cea mai redusă diferențiere între valorile diversității specifice corespunzătoare diferitelor tipuri de disturbanțe, la altitudinile superioare (clasele 900 și 1100 m) se observă o segregare mai clară, nu doar între disturbanțele mixte și antropice ci între toate scenariile disturbanțelor considerate, aspect mai evident în clasa altitudinală de 1100 de m. Această tendință, de diferențiere mai clară a diversității între scenarii la creșterea altitudinii, arată sensibilitatea diversității la modificarea acestui factor, aspect sesizat și în alte studii. Redowan (2015) a observat aceeaşi influență, subliniind că nu poate fi interpretată totuşi ca fiind general valabilă în ecosistemele forestiere, explicând că mai degrabă tipurile de vegetație au un tipar altitudinal diferit, ce poate să determine această reacție.

La nivelul diferențelor date de expoziție, temperamentul speciilor are un rol considerabil, diversitatea relaţionând intens cu temperamentul speciilor (Schuler et al. 2017, Varga et. al. 2005).

În cazul de față, speciile majoritare de la care pornește simularea au un pronunțat temperament de umbră (brad și fag) și reușesc mai greu să își creeze condiţii optime de regenerare pe expozițiile însorite. $\mathrm{Cu}$ toate acestea, din punctul de vedere al managementului silvic, ale cărui efecte sunt integrate în simularea disturbanțelor antropice, aceste specii sunt preferate și avantajate în regenerare de forestieri. Rezultatele evidențiate grafic (Fig. 5) arată că disturbanțele antropice la altitudinile superioare (900 și 1100 m) reușesc să conducă sau să păstreze valori ridicate ale diversității specifice, cu excepția simulărilor pe expoziţia însorită. În cazul expoziției însorite se poate observa că diversitatea înregistrează valori mai scăzute sau în descreștere în cazul tuturor claselor altitudinale. Această observație prezintă importanță practică, ce poate să conducă la modificarea modului în care actualele tăieri de regenerare sunt aplicate în arboretele cu aceste expoziții.

Sensibilitatea maximă la efectele induse de expoziție par să se înregistreze la altitudinile cele mai mici, rezultatele evidențiate grafic (Fig. 5) arătând că, în clasa de 500 de metri altitudine, evoluția diversității este foarte diferită pentru toate clasele de expoziție. Observația poate fi nuanțată, luând și un caracter mai general iar pe baza rezultatelor se poate aprecia 
că, la altitudinile extreme, evoluția diversitătii este mai sensibilă la expoziție comparativ cu altitudinile intermediare, care oferă o diversitate specifică relativ constantă în cazul disturbanțelor mixte și antropice, dar și o diferențiere mai evidentă a diversității între scenarii.

Un alt aspect interesant se referă la faptul că, indiferent de clasa altitudinală, disturbanțele antropice și mixte simulate cresc sau mențin relativ constantă diversitatea specifică pe expoziţia parțial însorită. Acest profil de expoziție pare să fie mai stimulativ pentru specii, diversitatea fiind superioară celor înregistrate pe celelalte expoziții.

\section{Concluzii}

Articolul de față răspunde nevoii, identificate în numeroase studii, de a culege mai multe informații relevante legate de modul în care disturbanţele afectează ecosistemele forestiere, tocmai pentru a rezolva sau explica anumite rezultate contradictorii obținute în decursul timpului.

Rezultatele simulărilor prezintă modul în care disturbanțele pot influența evoluția diversității în funcție de altitudine și expoziție. Desigur, modul în care disturbanțele pot modifica diversitatea specifică este în strânsă legătură cu structura și compoziţia arboretelor, managementul silvic urmărind să asigure structuri și compoziții adecvate și pregătite pentru a face față unor noi provocări climatice.

Modul în care acționează disturbanțele și produc efecte trebuie nu doar înțeles, dar şi încorporat în sistemul de management forestier. Efectele pozitive, cu referire directă la creșterea diversității specifice, ar trebui valorificate, prin păstrarea speciilor pioniere iniţial instalate. Acțiunea naturii și a silvicultorului ar trebui să fie măcar parțial convergentă, evitând omogenizarea specifică excesivă a arboretelor, impusă uneori de normative tehnice specifice prea rigide care limitează numărul de specii din schemele de regenerare.

Folosirea reactiei naturale a unui ecosistem și încorporarea efectelor pozitive ale disturbanțelor naturale în managementul silvic poate reprezenta o modalitate adecvată de creare a unor arborete adaptate noilor realități climatice.

\section{Mulțumiri}

Pentru CC articolul a fost finanțat de proiectul "DECIDE - Dezvoltare prin educație antreprenorială și cercetare inovativă doctorală și postdoctorală”, Cod proiect POCU/380/6/13/125031, proiect cofinanțat din Fondul Social European prin Programul Operațional Capital Uman 2014-2020. Pentru $\mathrm{CP}$ articolul a fost finantat de proiectul European H2020 BeonNAT (H2020-BBI-JTI-2019/BBI2019-SO1-R1), grant nr. 887917. Pentru LB articolul a fost finanțat de proiectul European H2020 Grant 817903 EFFECT.

\section{Bibliografie}

Abensperg-Traun M., Smith G. T. , Arnold G. W., D. Steven E., 1996. The Effects of Habitat Fragmentation and Livestock-Grazing on Animal Communities in Remnants of Gimlet Eucalyptus Salubris Woodland in the Western Australian Wheatbelt. I. Arthropods. The Journal of Applied Ecology 33(6): 1281. https://doi. org/10.2307/2404770

Ammer C., 2019. Diversity and Forest Productivity in a Changing Climate. New Phytologist 221(1): 50-66. https://doi.org/10.1111/nph.15263

Anonymous. 2010. Amenajament ocol silvic Râșca.

Battisti C., Poeta G., Fanelli G., 2016. An Introduction to Disturbance Ecology. Cham: Springer International Publishing. http://link.springer.com/10.1007/978-3319-32476-0

Bouriaud L., Bouriaud O., Elkin C., Temperli C., Reyer C., Duduman G., Barnoaiea I., Nichiforel L., Zimmermann N., Bugmann H. 2014. Age-Class Disequilibrium as an Opportunity for Adaptive Forest Management in the Carpathian Mountains, Romania. Regional Environmental Change. https://doi.org/10.1007/s10113014-0717-6

Brose U., Helmut H., 2016. Biodiversity and Ecosystem Functioning in Dynamic Landscapes. Philosophical Transactions of the Royal Society B: Biological Sciences 371(1694). https://doi.org/10.1098/rstb.2015.0267

Brunialti G., Luisa F., 2021. Modeling of Species Distribution and Biodiversity in Forests. Forests 12(3): 1-3. 
https://doi.org/10.3390/f12030319

Burlui I., 2013. Managementul Riscului de Incendiu În Pădurile Judeţului Suceava. Teză de doctorat, Universitatea „Ștefan cel Mare” din Suceava, 160p.

Feng G., Svenning J.C., Mi X., Jia Q., Rao M., Ren H., Bebber D.P., Ma K., 2014. Anthropogenic Disturbance Shapes Phylogenetic and Functional Tree Community Structure in a Subtropical Forest. Forest Ecology and Management 313: 188-98. http://dx.doi.org/10.1016/j. foreco.2013.10.047.

Gaston K.J., 2000. Global Patterns in Biodiversity. Nature 405(6783): 220-27. https://doi.org/10.1038/35012228

He H.S., 2008. Forest Landscape Models: Definitions, Characterization, and Classification. Forest Ecology and Management 254(3): 484-98. https://doi.org/10.1016/j. foreco.2007.08.022

Henne P.D., Elkin C., Colombaroli D., Samartin S., Bugmann H., Heiri O., Tinner W., 2013. Impacts of Changing Climate and Land Use on Vegetation Dynamics in a Mediterranean Ecosystem: Insights from Paleoecology and Dynamic Modeling. Landscape Ecology 28(5): 819-33.https://doi.org/10.1007/s10980-012-9782-8

IPCC., 2007. Climate Change 2007: Impacts, Adaptation and Vulnerability. Contribution of Working Group II to the Fourth Assessment Report of the Intergovernmental Panel on Climate Change. eds. P.J. van der Linden and C.E. M.L. Parry, O.F. Canziani, J.P. Palutikof and Hanson. Cambridge, UK: Cambridge University Press.

Isbell F., Calcagno V., Hector A., Connolly J., Harpole W.S., Reich P.B., Scherer-Lorenzen M., Schmid B., Tilman D., Van Ruijven J., Weigelt A., Wilsey B.J., Zavaleta E.S., Loreau M., 2011. High Plant Diversity Is Needed to Maintain Ecosystem Services. Nature 477(7363): 199-202. https://doi.org/10.1038/nature10282

Jiang Y., Muyi K., Yuan Z.,Guangcai X., 2007. Plant Biodiversity Patterns on Helan Mountain, China. Acta Oecologica 32(2): 125-33. https://doi.org/10.1016/j. actao.2006.12.003

Jullien M., Thiollay J.-M., 1996. Effects of Rain Forest Disturbance and Fragmentation: Comparative Changes of the Raptor Community along Natural and Humanmade Gradients in French Guiana. Journal of Biogeography 23(1): 7-25. https://doi.org/10.1046/j.13652699.1996.00963.x

Kjellström E., Nikulin G., Hansson U., Strandberg G., Ullerstig A., 2011. 21st Century Changes in the European Climate: Uncertainties Derived from an Ensemble of Regional Climate Model Simulations. Tellus, Series A: Dynamic Meteorology and Oceanography 63(1): 24-40. https://doi.org/10.1111/j.1600-0870.2010.00475.x

Mackey R.L., David J.C., 2001. The diversity-disturbance relationship: is it generally strong and peaked? Ecology 82(12): 3479-92. https://doi.org/10.1890/0012-9658(20 01)082[3479:TDDRII]2.0.CO;2

Marcean M., 2002. Pădurile Sucevei Şi Calamităţile Din Perioada 1945-2002. Bucovina Forestiera X(1-2): 59-73.

Martinsen G.D, Cushman J.H., Whitham T.G. 1990. Impact of Pocket Gopher Disturbance on Plant Species Di- versity in a Shortgrass Prairie Community. Oecologia 83. https://doi.org/10.1007/BF00324644

Miller A.D, Roxburgh S.H., Shea K., 2011. How Frequency and Intensity Shape Diversity-Disturbance Relationships. Applied Mathematics Ecology, 108(14): 564348. https://doi.org/10.1073/pnas.1018594108

Mina M., Huber M.O., Forrester D.I., Thürig E., Rohner B., 2017. Future Ecosystem Services from European Mountain Forests under Climate Change. Journal of Applied Ecology 54: 389-401. https://doi. org/10.1111/1365-2664.12772

Mittelbach G.G., Schemske D.W., 2015. Ecological and Evolutionary Perspectives on Community Assembly. Trends in Ecology and Evolution 30(5): 241-47. https:// doi.org/10.1016/j.tree.2015.02.008

Nadrowski K., Wirth C., Scherer-Lorenzen M., 2010. Is Forest Diversity Driving Ecosystem Function and Service? Current Opinion in Environmental Sustainability 2(1-2): 75-79. https://doi.org/10.1016/j.cosust.2010.02.003

Neumann M., Starlinger F., 2001. The Significance of Different Indices for Stand Structure and Diversity in Forests. Forest Ecology and Management 145(1-2): 91106. https://doi.org/10.1016/S0378-1127(00)00577-6

Palaghianu C., 2014. A Tool for Computing Diversity and Consideration on Differences between Diversity Indices. Journal of Landscape Management 5(2): 78-82.

Pickett S.TA, White P.S., 2013. The Ecology of Natural Disturbance and Patch Dynamics. ed. Peter S. White Pickett, Steward TA. Elsevier.

Pommerening A., 2002. Approaches to Quantifying Forest Structures. Forestry 75(3): 305-24. https://doi. org/10.1093/forestry/75.3.305

Pontarp M., Bunnefeld L., Cabral J.S., Etienne R.S., Fritz S.A., Gillespie R., Graham C.H., Hagen O., Hartig F., Huang S., Jansson R., Maliet O., Münkemüller T., Pellissier L., Rangel T.F., Storch D., Wiegand T., Hurlbert A.H., 2019. The Latitudinal Diversity Gradient: Novel Understanding through Mechanistic Eco-Evolutionary Models. Trends in Ecology and Evolution 34(3): 21123. https://doi.org/10.1016/j.tree.2018.11.009

Popa I., 2004. Doborâturi Produse De Vânt - Factor De Risc În Ecosistemele. Analele ICAS 48: 3-28.

R Core Team., 2019. R: A Language and Environment for Statistical Computing. R Foundation for Statistical Computing. https://www.r-project.org/. (May 20, 2019).

Rangel T.F., Edwards N.R., Holden P.B., Diniz-Filho J. A.F., Gosling W.D., Coelho M.T.P., Cassemiro F.A.S., Rahbek C., Colwell R.K., 2018. Modeling the Ecology and Evolution of Biodiversity: Biogeographical Cradles, Museums, and Graves. Science 361(6399). https:// doi.org/10.1126/science.aar5452

Read Q.D., Zarnetske P.L., Record S., Dahlin K.M., Costanza J.K., Finley A.O., Gaddis K.D., Grady J.M., Hobi M.L., Latimer A.M., Malone S.L., Ollinger S.V., Pau S., Wilson A.M., 2020. Beyond Counts and Averages: Relating Geodiversity to Dimensions of Biodiversity ed. Volker Bahn. Global Ecology and Biogeography 29(4): 
696-710. https://doi.org/10.1111/geb.13061

Redowan M., 2015. Spatial Pattern of Tree Diversity and Evenness across Forest Types in Majella National Park, Italy. Forest Ecosystems 2(1). https://doi.org/10.1186/ s40663-015-0048-1

Robin Svensson J., Lindegarth M., Jonsson P.R, Pavia H., 2012. Disturbance-Diversity Models: What Do They Really Predict and How Are They Tested? Proceedings of the Royal Society B: Biological Sciences 279(1736): 2163-70. https://doi.org/10.1098/rspb.2011.2620

Rykiel E.J., 1985. Towards a Definition of Ecological Disturbance."Australian Journal of Ecology 10(3): 361-65. https://doi.org/10.1111/j.1442-9993.1985.tb00897.x

Scheller R.M., Mladenoff D.J., 2007. An Ecological Classification of Forest Landscape Simulation Models: Tools and Strategies for Understanding Broad-Scale Forested Ecosystems. Landscape Ecology 22(4): 491505. https://doi.org/10.1007/s10980-006-9048-4

Schuler L.J., Bugmann H., Petter G., Snell R.S., 2019. How Multiple and Interacting Disturbances Shape Tree Diversity in European Mountain Landscapes. Landscape Ecology 34(6): 1279-94. https://doi.org/10.1007/ s10980-019-00838-3

Schuler L.J., Bugmann H., Snell R.S., 2017. From Monocultures to Mixed-Species Forests: Is Tree Diversity Key for Providing Ecosystem Services at the Landscape Scale? Landscape Ecology 32(7): 1499-1516. https:// doi.org/10.1007/s10980-016-0422-6

Schumacher S., 2004. PhD thesis - Synthesis The Role of Landscapes in the European Alps.

Schumacher S., Bugmann H., 2006. The Relative Importance of Climatic Effects, Wildfires and Management for Future Forest Landscape Dynamics in the Swiss Alps. Global Change Biology 12(8): 1435-50. https:// doi.org/10.1111/j.1365-2486.2006.01188.x

Schumacher S., Reineking B., Sibold J., Bugmann H. ,2006. Modeling the Impact of Climate and Vegetation on Fire Regimes in Mountain Landscapes. : 1-45. https://doi.org/10.1007/s10980-005-2165-7

Seidl R., Fernandes P.M., Fonseca T.F., Gillet F., Jönsson A.M., Merganičová K., Netherer S., Arpaci A., Bontemps J.D., Bugmann H., González-Olabarria J.R., Lasch P., Meredieu C., Moreira F ., Schelhaas M.J., Mohren F., 2011. Modelling Natural Disturbances in Forest Ecosystems: A Review. Ecological Modelling 222(4): 903-24. https://doi.org/10.1016/j.ecolmodel.2010.09.040

Seidl R., 2017. Forest Disturbances under Climate Change. Nature Climate Change 7(6). https://doi.org/10.1038/ nclimate 3303

Seidl R., Schelhaas M.J., Rammer W., Verkerk P.J., 2014. Increasing Forest Disturbances in Europe and Their Impact on Carbon Storage. Nature Climate Change 4(9): 806-10. https://doi.org/10.1038/nclimate2318

Shea K., Roxburgh S.H., Rauschert E.S.J., 2004. Moving from Pattern to Process: Coexistence Mechanisms under Intermediate Disturbance Regimes. Ecology Letters 7(6): 491-508. https://doi.org/10.1111/j.1461- 0248.2004.00600.x

Silva Pedro M., Rammer W., Seidl R., 2016. A Disturbance-Induced Increase in Tree Species Diversity Facilitates Forest Productivity. Landscape Ecology 31(5): 989-1004. https://doi.org/10.1007/s10980-015-0317-y

Simionescu A., Chira D., Mihalciuc V., Ciornei C., Tulbure C., 2012. Starea de Sănătate a Pădurilor Din România În Perioada 2001-2010. Suceava: Editura Mușatinii.

Snell R.S., Elkin C., Kotlarski S., Bugmann H., 2018. Importance of Climate Uncertainty for Projections of Forest Ecosystem Services. Regional Environmental Change. https://doi.org/10.1007/s10113-018-1337-3

Sousa W.P., 1984. The Role of Disturbance in Natural Communities. Annual Review of Ecology and Systematics 15(1): 353-91. https://doi.org/10.1146/annurev.es.15.110184.002033

Taylor A.R., Chen H.Y.H., VanDamme L., 2009. A Review of Forest Succession Models and Their Suitability for Forest Management Planning. Forest Science 55(1): 23-36.

Temperli C., Bugmann H., Elkin C.M., 2013. Cross-Scale Interactions among Bark Beetles, Climate Change, and Wind Disturbances : A Landscape Modeling Approach. Ecological Monographs 83(3): 383-402. https://doi. org/10.1890/12-1503.1

Thrippleton T., Bugmann H., Folini M., Snell R.S., 2018. Overstorey-Understorey Interactions Intensify After Drought-Induced Forest Die-Off: Long-Term Effects for Forest Structure and Composition. Ecosystems 21(4): 723-39. https://doi.org/10.1007/s10021-0170181-5

Varga P., Chen H.Y.H., Klinka K., 2005. Tree-Size Diversity between Single- and Mixed-Species Stands in Three Forest Types in Western Canada. Canadian Journal of Forest Research 35(3): 593-601. https://doi. org/10.1139/x04-193

White P.S., 1979. Pattern, Process, and Natural Disturbance in Vegetation. The Botanical Review 45(3): 22999. https://doi.org/10.1007/BF02860857

White P.S., Jentsch A., 2001. The Search for Generality in Studies of Disturbance and Ecosystem Dynamics. In Springer, Berlin, Heidelberg, 399-450. https://doi. org/10.1007/978-3-642-56849-7_17

Yeboah D., Chen H.Y.H., 2016. Diversity-Disturbance Relationship in Forest Landscapes. Landscape Ecology 31(5): 981-87. https://doi.org/10.1007/s10980-015-0325-y

Zimmermann N.E., Gebetsroither E., Zuger J., Schmatz D., Psomas A., 2013. Future Climate of the European Alps. Management Strategies to Adapt Alpine Space Forests to Climate Change Risks (Ipcc 2007).

*** World Imagery Sources: Esri, DigitalGlobe, GeoEye, i-cubed, USDA FSA, USGS, AEX, Getmapping, Aerogrid, IGN, IGP, swisstopo, and the GIS User Community

*** Maps throughout this article were created using ArcGIS ${ }^{\circledR}$ software by Esri. ArcGIS ${ }$ and $\operatorname{ArcMap}^{\mathrm{TM}}$ are the intellectual property of Esri and are used herein under license. Copyright (C) Esri. All rights reserved. For more information about Esri ${ }^{\circledR}$ software, please visit www.esri.com 